
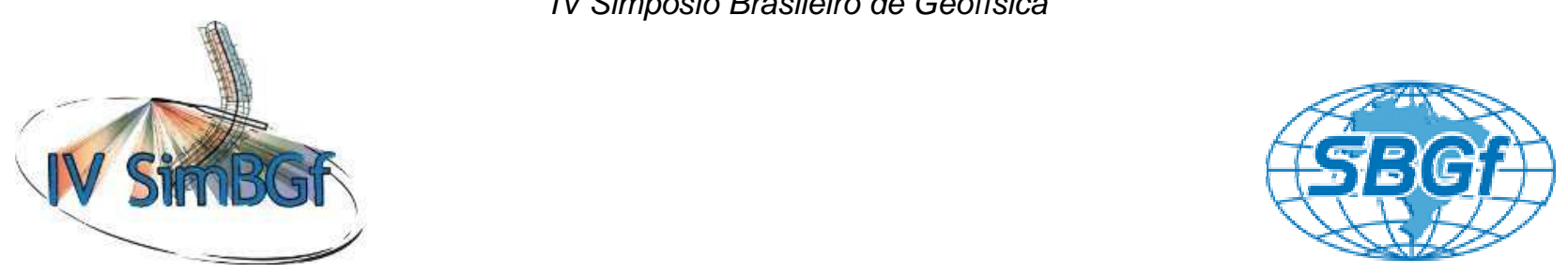

\title{
Geophysical characteristics of the Neoproterozoic Amazon Plate-Tocantins Province suture in central Brazil
}

José Eduardo P. Soares, Lucas Coutrim C. P. Caridade, Reinhardt A. Fuck

Laboratório de Estudos da Litosfera/IG/UnB

Copyright 2010, SBGf - Sociedade Brasileira de Geofísica

Este texto foi preparado para a apresentação no IV Simpósio Brasileiro de Geofísica, Brasília, 14 a 17 de novembro de 2010. Seu conteúdo foi revisado pelo Comitê T́́cnico do IV SimBGf mas na ne 2010. Seu consariante representa a opinia pela CBGf ou Ténico do IV SinBGr, É proibida necessariamente representa a opiniăo da SBGf ou de seus associados. E proibida a reprodução total ou parcial deste material para

\section{Abstract}

An array of six broadband seismographic stations was installed in central Brazil, covering the transition between the Tocantins Province and the Amazon paleoplate along two NW-SE profiles, with the aim to imaging the structure of the crust in the region. Using teleseismic event recordings, we were able to determine the $\mathrm{Vp} / \mathrm{Vs}$ ratio and the crustal thickness under the stations, applying the receiver function method. The results allow to conclude that: i) the crust is anomalously thick $(\sim 50 \mathrm{~km})$ in the transition region, which grossly coincides with the gravimetric gradient anomaly of central Brazil. It marks the collision front between the two provinces; ii) the crust thins away from the suture, tending to be thicker under the Amazon paleoplate than below the Tocantins Province, and iii) the crust thickens northwards.

\section{Introduction}

The Tocantins Province, in central Brazil, is the result of convergence of the São Francisco, Amazon and Paranapanema paleoplates during the Neoproterozoic Brasiliano orogeny. The northern part of the province, formed between the São Francisco and Amazon paleoplates, displays a NE-SW geological trend, which is roughly coincident with the direction of a regional gravimetric high (200 km wide, $700 \mathrm{~km}$ long) that stands out in central Brazil. Integrated interpretation of deep seismic refraction and gravimetric data has shown that the gravimetric high reflects a corridor of shallow Neoproterozoic lid mantle which is denser, hotter and probably less depleted than the neighboring Paleoproterozoic and Archean mantle tracts related to the São Francisco and Amazon plates, respectively. In contrast with the São Francisco Plate border, the behavior of the crust in the transition Amazon Plate-Tocantins Province is poorly known. In order to determine the crustal behavior in this limit the Lithosphere Research Lab./IG/UnB installed six broadband stations across the western limit of the gravimetric high (herein called west gravimetric gradient). Stations were deployed along two NW-SE profiles: i) one close to $13^{\circ} \mathrm{S}$, where two seismographic stations (RET8 e RET9) complement the previous deep refraction profile (one station is placed on the gravimetric gradient and the other to the northwest of it); ii) the second profile, close to $12^{\circ} \mathrm{S}$, comprises three seismographic stations (RET2, RET3 e RET4) installed on the gravimetric gradient, and to the west and east of it (Figure 1).

Northwards, in the Porto Nacional Complex, an additional seismographic station (RET1) was recently installed, placed in the domain of the gravimetric high, for which preliminary results are shown.

\section{Methodology}

Receiver function is a technique applied on teleseismic data records to infer the crustal structure under the seismographic stations.

It is a method that allows to obtain the mean $\mathrm{Vp} / \mathrm{Vs}$ ratio and the thickness of the crust under seismographic stations, through the arrival time of Ps ( $P$ converted in $S$ in the Moho) and PpPms (S multiple) phases, setting the average crustal $\mathrm{Vp}$, according to the relations below (Zandt and Ammon, 1995; Zandt et al., 1995):

$$
\begin{gathered}
\frac{V_{P}}{V_{S}}=\left\{\left(1-p^{2} V_{P}^{2}\right)\left[2\left(\frac{t_{P_{S}}-t_{P}}{t_{P p P m s}-t_{P_{S}}}\right)+1\right]^{2}+p^{2} V_{P}^{2}\right\}^{1 / 2} . \\
H=\frac{V_{P}\left(t_{P_{S}}-t_{P}\right)}{\left(\sqrt{\frac{V_{P}^{2}}{V_{S}^{2}}-p^{2} V_{P}^{2}}-\sqrt{1-p^{2} V_{P}^{2}}\right)},
\end{gathered}
$$

where $\mathrm{p}$ is the ray parameter, $\mathrm{H}$ the crustal thickness and $t$ the arrival time of the phases. 


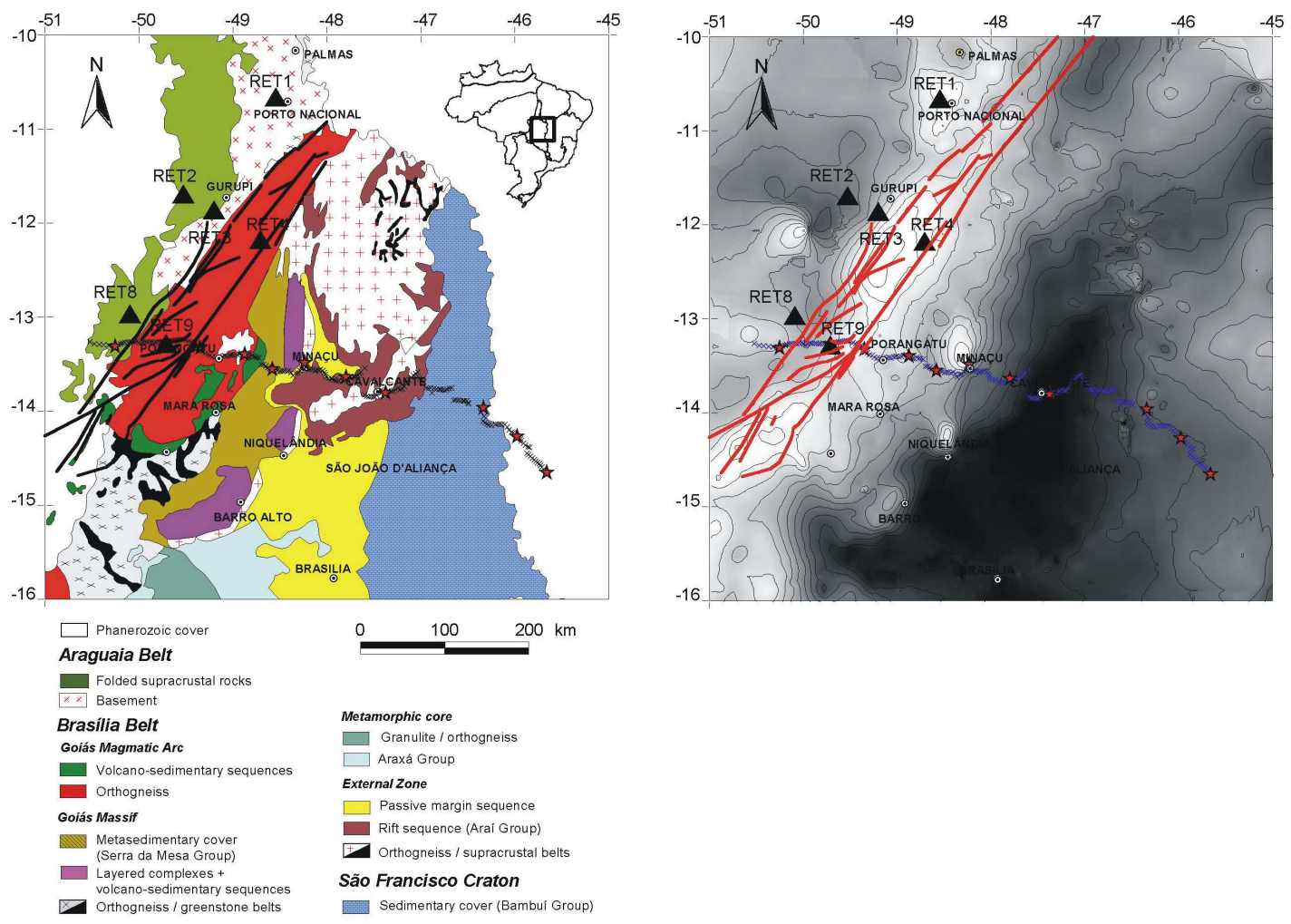

Figure 1 - Geological and Bouguer gravimetric maps of central Brazil showing: i) previous deep seismic refraction line, represented by blue $\mathrm{x}$ (receivers) and red stars (shots); ii) broadband seismographic stations represented by black triangles, and iii) Transbrasiliano Lineament, represented by NE lines. The regional high Bouguer gravimetric anomaly represents variations in the composition of lithosphere mantle of central Brazil.

The Ps and PpPms phases are obtained deconvolving the vertical component of teleseismic records from the radial and transversal ones. The receiver function traces with similar ray parameters $(p)$ were stacked (Figure 2$)$ and the $\mathrm{Vp} / \mathrm{Vs}$ ratio and crustal thickness $(\mathrm{H})$ were obtained with the H-K stacking program (Zhu e Kanamori, 2000) (Figure 3).

As $\mathrm{Vp}$ is unknown, in this work the crustal $\mathrm{Vp} / \mathrm{Vs}$ and $\mathrm{H}$ were calculated to $V p$ of $6.3 \mathrm{~km} / \mathrm{s}$ and $6.7 \mathrm{~km} / \mathrm{s}$, which means minimum and maximum crustal thickness, respectively. Changing $\mathrm{Vp}$, the $\mathrm{Vp} / \mathrm{Vs}$ changes slightly. The exception is the RET9 station where refraction studies suggest $\mathrm{Vp}$ of $7.0 \mathrm{~km} / \mathrm{s}$ for the crust (Ventura, 2010).

\section{Results}

The $\mathrm{Vp} / \mathrm{Vs}$ and crustal thickness results are summarized in Table 1.

\section{Discussion}

These results indicate that:

i) the crust is thicker along the gravimetric gradient than in the Amazon paleoplate and Tocantins Province;

ii) along the seismic profile Moho presents a step of 14 $\mathrm{km}$ at the transition zone (gravimetric gradient), suggesting lower crust duplication, probably related to Amazon paleoplate subduction under the Tocantins Province;

iii) inside each domain the crust is not homogeneous, tending to be thicker northwards; 


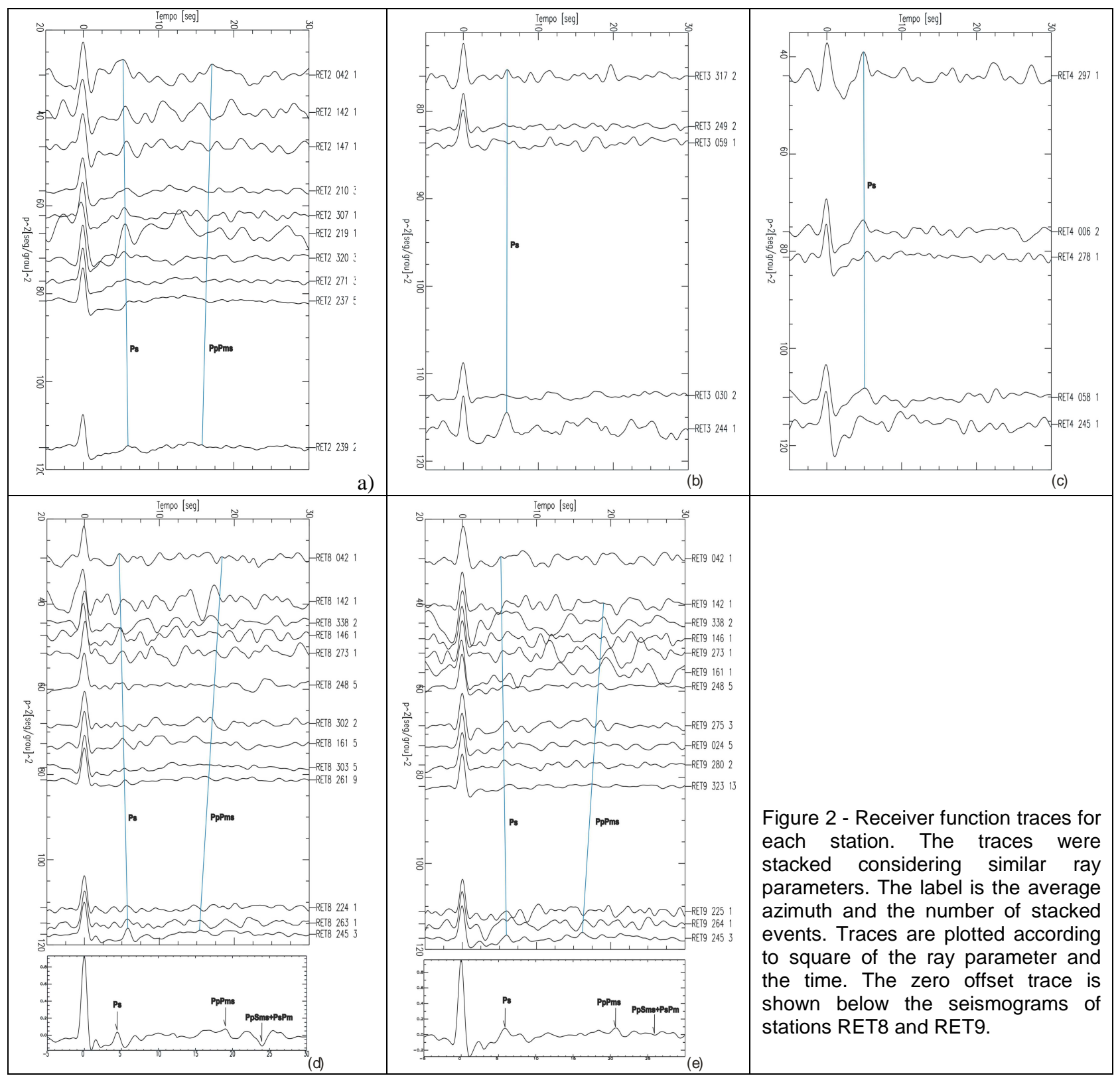

iv) the central Brazil gravimetric high reflects density variation within lithospheric mantle, and in view of $\mathrm{Vp}$ of $8.05 \mathrm{~km} / \mathrm{s}$ (Soares et al., 2006) and density of $3.3 \mathrm{~g} / \mathrm{cm}^{3}$ (Ventura, 2010), it probably represents undepleted Neoproterozoic mantle;

v) the crust of the Amazon paleoplate $(\mathrm{Vp} / \mathrm{Vs}$ of 1.78$)$ is different from the crust of Tocantins Province $(\mathrm{Vp} / \mathrm{Vs}$ of 1.72);

vi) the lower crust of the Amazon paleoplate is of mafic composition; vii) along the refraction profile $\left(13^{\circ} \mathrm{S}\right)$, the Transbrasiliano Lineament coincides with the collisional front. Northwards it goes to NE while the suture bends to NW.

\section{Conclusion}

The western limit of the Bouguer gravimetric high in central Brazil is the collision front between the Amazon paleoplate and the Tocantins Province. It separates crust and lithosphere of different composition and thickness. 


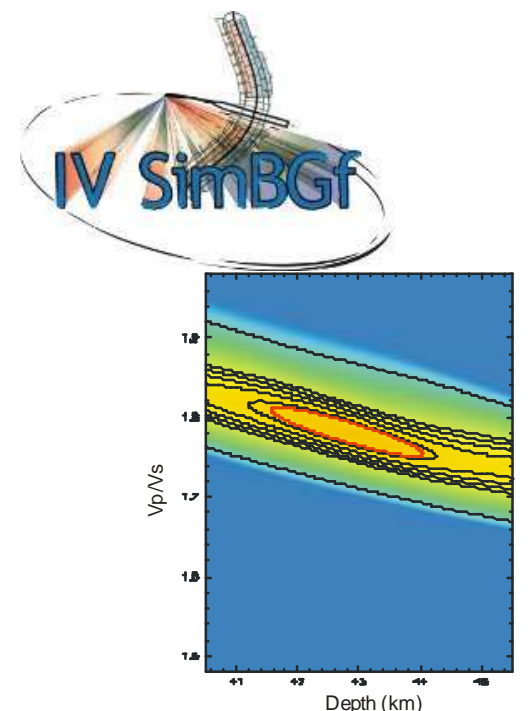

$\mathrm{Vp}=6.3 \mathrm{Km} / \mathrm{s} ; \mathrm{h}=42.8+-2.5 \mathrm{~km}$;

$\mathrm{Vp} / \mathrm{Vs}=1.78+-0.06$

correlation $=-90.6 \%$

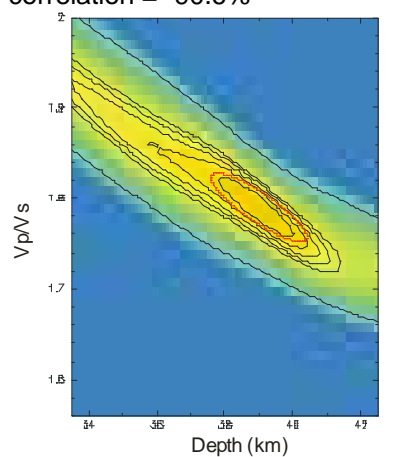

$V p=6.3 \mathrm{~km} / \mathrm{s} ; \mathrm{h}=39+-2.8 \mathrm{~km}$;

$\mathrm{Vp} / \mathrm{Vs}=1.79+-0.08$

correlation $=-86.6 \%$

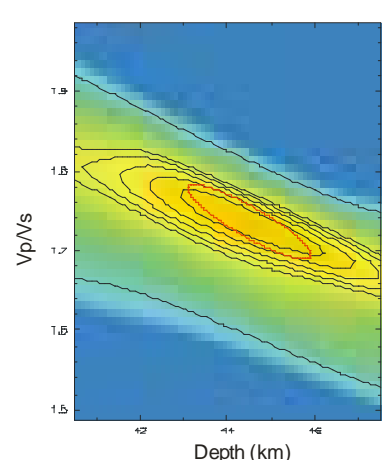

$\mathrm{Vp}=6.3 \mathrm{~km} / \mathrm{s} ; \mathrm{h}=44.5+-2.8 \mathrm{~km}$;

$\mathrm{Vp} / \mathrm{Vs}=1.74+-0.09$

correlation $=-88.9 \%$

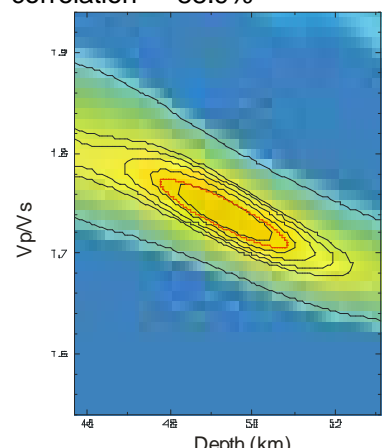

$\mathrm{Vp}=6.7 \mathrm{~km} / \mathrm{s} ; \mathrm{h}=49.3+-3.1 \mathrm{~km}$;

$\mathrm{Vp} / \mathrm{Vs}=1.74+-0.07$

correlation $=-89.8 \%$

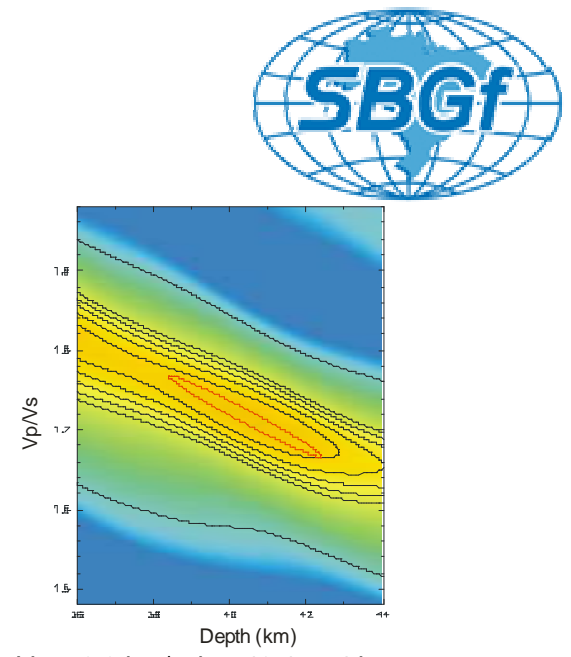

$\mathrm{Vp}=6.3 \mathrm{~km} / \mathrm{s} ; \mathrm{h}=40.4+-4 \mathrm{~km}$;

$\mathrm{Vp} / \mathrm{Vs}=1.72+-0.1$

correlation $=-98.3 \%$

Figure 3 - HK-stack, from left to right and up to down, of RET2, RET3, RET4, RET8 and RET9 stations for $\mathrm{Vp}=6.3 \mathrm{~km} / \mathrm{s}$.

Table 1 - Receiver function results for the central Brazil seismographic array

\begin{tabular}{|c|c|c|c|c|c|}
\hline Station & $\begin{array}{c}\text { Coordinates } \\
\text { Lat. }\left({ }^{0}\right) / \text { Long. }\left({ }^{0}\right)\end{array}$ & $\mathrm{Vp} / \mathrm{Vs}$ & $\mathrm{Vp}(\mathrm{km} / \mathrm{s})$ & $\mathrm{H}(\mathrm{km})$ & Geological Setting \\
\hline RET1 & $-10.67 /-48.55$ & 1.72 & 6.3 & $42.5^{\star}$ & $\begin{array}{l}\text { Porto Nacional complex } \\
\text { Gravimetric high }\end{array}$ \\
\hline RET2 & $-11.70 /-49.53$ & $1.79 / 1.76$ & $6.3 / 6.7$ & $42.8 / 46.3$ & $\begin{array}{c}\text { Araguaia Belt } \\
\text { Gravimetric low }\end{array}$ \\
\hline RET3 & $-11.87 /-49.21$ & $1.74 / 1.71$ & $6.3 / 6.7$ & $44.5 / 48.4$ & $\begin{array}{c}\text { Araguaia Belt } \\
\text { Gravimetric gradient }\end{array}$ \\
\hline RET4 & $-12.19 /-48.71$ & $1.72 / 1.70$ & $6.3 / 6.7$ & $40.4 / 43.5$ & $\begin{array}{l}\text { Goiás Magmatic Arc } \\
\text { Gravimetric high }\end{array}$ \\
\hline RET8 & $-12.97 /-50.10$ & $1.79 / 1.77$ & $6.3 / 6.7$ & $39.0 / 42.6$ & $\begin{array}{c}\text { Araguaia Belt } \\
\text { Gravimetric low }\end{array}$ \\
\hline RET9 & $-13.29 /-49.72$ & 1.74 & 7.0 & 52.4 & $\begin{array}{c}\text { Araguaia Belt } \\
\text { Gravimetric gradient }\end{array}$ \\
\hline
\end{tabular}

${ }^{*}$ Preliminary result. 


\section{Acknowledgments}

The authors thank FAPDF (grant 193.000.209/2007 to $\mathrm{RAF}$ ) and CNPq (grant 48.0166/2008-0) for financial support. LCCPC acknowledges PIBIC scholarship (Decanato de Pesquisa e Pós-graduação/UnB and CNPq). Dr. M. P. Rocha is thanked for valuable help with computational codes and confection of scripts.

\section{References}

Soares J.E.P., Berrocal J., Fuck R.A., Mooney W.M., Ventura D.B.R.V. 2006. Seismic characteristics of central Brazil crust and upper mantle: a deep seismic refraction study. Journal of Geophysical Research, vol. 111, B112302, doi 10.1029/2005JB003769.

Ventura, D.B.R. 2010. Parâmetros elásticos da crosta sob a linha de refração sísmica profunda de Porangatu (GO).
Universidade de Brasília, Programa de Pós-Graduação em Geociências (Dissertação de Mestrado nr. 8), 117 p., anexos.

Zandt, G. and Ammon, C.J. 1995. Continental crust composition constrained by measurements of crustal Poisson's ratio. Nature, vol 374:152-154.

Zandt, G., Myers, S.C., Wallace, T.C. 1995. Crust and mantle structure across the Basin and Range-Colorado Plateau boundary at $37^{\circ} \mathrm{N}$ latitude and implications for Cenozoic extensional mechanism. Journal of Geophysical Research, vol 100:10529-10548.

Zhu, L. e Kanamori, H., 2000. Moho depth variation in southern California from teleseismic receiver functions. Journal of Geophysical Research, vol. 105, B2, 26962980. 